\title{
LHP: ROSS
}

\section{RHP: INTERSECTING IDENTITIES}

14

\section{INTERSECTING IDENTITIES: YOUNG PEOPLE'S CONSTRUCTIONS OF IDENTITY IN SOUTH-EAST EUROPE}

Alistair Ross

\section{$<$ A $>$ INTRODUCTION}

This chapter examines a different kind of intersection than that considered elsewhere in this volume: that between potentially conflicting territorial or political identities of the self that arise as young people in Bulgaria and Romania attempt to reconcile their potential memberships of a national community, a regional Balkan identity, and a European identity. The educational implications of this analysis relate to young people in a much wider context than these two south-eastern European countries. At the time of writing, they are the most recent members of the European Union, joining in 2007, but they will have been joined by Croatia by the time this book is published, and very likely within the next four to six years by six or seven other Balkan states. Some of the implications will resonate much more widely than the Balkan peninsular: The tensions of multiple membership of different and nesting political entities, and of being a 'global citizen' are becoming more common and pressing across Europe and beyond. 
McCall (2005) describes intersectionality as 'the relationship among multiple dimensions and modalities of social relations and subject formations' (1171). She also interprets the term as encompassing 'perspectives that completely reject the separability of analytic and identity categories' (1171, footnote 1$)$. The traditional axes of identity used in intersectionality (e.g. Crenshaw 1991; Collins 2000; Siltanen and Doucet 2008) were gender and race, to which social class, ethnicity and ability have often been added. Intersectionality theory suggests that social oppression is not based on these factors in a way that is independent of each other, but that they interrelate and intersect to create multiple forms of oppression and discrimination (e.g. Ritzer 2007).

In this chapter, other potentially intersecting dimensions are added to this. The constructions of identity by young people in south-eastern Europe - in particular in the two Black Sea states of Bulgaria and Romania - are structured in part by dimensions of nationality, regionalism and Europeanisation. These shape, and are shaped by, each other to create a tangled and complex nexus of suppressed or oppressed identities. This 'multidimensional conceptualisation' (Browne and Misra 2003) may help explain how socially constructed categories of difference interact to create a hierarchy of social identities in these young people. Following McCall's (2005) categorisation of approaches to intersectionality, I am here using both intercategorical and intracategorical stances: I both use the existing categorical distinctions of nationality, regionality and Europeanism and at the same time question their utility and relevance in the contemporary context. In doing this, I am simply reflecting the constructions advanced by the young people themselves who, while readily employing these categories, at the same time struggle with the distinctions and 
contradictions between them. They appear to recognise that they, and their generation, cross the boundaries of constructed categories.

The two countries analysed in this chapter are part of a much larger study of young peoples' constructions of identity in the newer states of Europe that I am conducting. This one-person study, under the aegis of Jean Monnet chair, is an investigation of how young people between twelve and eighteen conceptualise themselves in the changing political circumstances of Europe, and about how they see themselves as different to older generations. I am working in the string of countries that have either joined the European Union in the 2004-2008 expansion (Bulgaria, Cyprus, the Czech Republic, Estonia, Hungary, Latvia, Lithuania, Poland, Romania, Slovakia and Slovenia) or are currently candidate countries to become members (Croatia, Iceland, Macedonia and Turkey). The political status of many of these countries has changed over the past twenty years, from being behind the Iron Curtain to being part of the European Union, or about to join the Union — and in these particular countries, such as Bulgaria and Romania, young people in their teens will be the first generation to be born, and thus wholly socialised, within these new polities.

An individual's civic identity and citizenship has usually been singular, traditionally associated with a defined and exclusive area (Mackenzie 1978). However, this has in many cases become partially eroded through processes such as globalisation, largescale migration and the development of dual citizenship (Jopkke 2010). Those countries in the European Union now have a citizenship additional to the citizenship of their own country: they are also citizens of the European Union, and this gives 
them some rights and privileges that are superior to those given by their own country. Identities are increasingly recognised as being both multiple and constructed contingently, and may include a range of intersecting dimensions, including gender, age and region (Lutz, Kritzinger and Skirbekk 2006). How do young people manage to construct these related but different identities? Are there tensions between these constructions, or can they be reconciled (Licata, 2000)? Young people in these countries are attempting this in very different conditions to those experienced by their parents or their grandparents at the same age: Are they conscious of this? Does it make them feel different in any way?

\section{$<$ A $>$ METHODOLOGY}

These are complex questions. Rather than use questionnaires or interviews, both of which impose direction and meaning on the subject, I am using focus groups to stimulate discussions on these topics between small groups of young people (Marshall and Rossman 1999). Because this study is of how young peoples' ideas are socially constructed, and because social constructions are created through interaction in a social context, focus groups have the advantages of being able to allow the investigator a modest degree of access to the discourses they may use between themselves, and allowing the young people to an extent to set an agenda for what appears to them to be relevant to their own lives. They are not, of course, wholly free in this: I try to steer the conversation to cover the topics on which I am focusing, although they only discuss and reveal what they choose. I cannot always be sure of the meaning of the terms that they use, and to continually demand explanations would turn the discussion into an interrogation and vitiate the purpose of the focus group. Questionnaires pre-construct conceptualisations, putting words into the mouth of the 
respondent: I want to hear their own constructs. The discussions I have had are not simply a dialogue, but an interchange that is largely between the young people themselves, in which they use their own vocabulary and structures, not mine. A focus group is not simply a serial semi-structured interview, in which the same question is put in sequence to each member of the group. It is more of a discussion-primarily between the young people themselves - into which I put a number of issues on which to focus. They may be in the form of questions, but they are questions that are clearly structured to indicate that I do not know what the answer might be. I participate in the discussion—sometimes with phatic expressions or with gestures, to keep the conversation going, sometimes with naive requests for explanations, occasionally with a challenge or an assertion that one of them has contradicted themselves - but always in ways that show that I am listening to and respecting their opinions.

I have now conducted almost 160 focus groups, with over 970 young people in fifty different locations in these countries. In each of these locations one to three schools were selected in areas with different social backgrounds, and in most schools there was a group of twelve- to fifteen-year-olds and one of fifteen- to eighteen-year-olds. Permission was sought from the young people and, for those under sixteen, from their parents. The sample is not representative, nor was it intended to be, but it illustrates the diversity of views expressed.

In some countries I have to do this with simultaneous interpretation, particularly with younger age groups. This requires particularly sympathetic translators, well acquainted with the ideas I am seeking to explore: I have been particularly fortunate 
in having built up a network of colleagues in many of these countries who have helped me do this. The project would not have been possible without help from many people. ${ }^{1}$ Schools and parents have been recruited, arrangements made for visits and, critically, help given in translating many of the transcripts. With many older groups in both of these countries I was able to work most of the time in English, accompanied by interpreters who help translate particular phrases or vocabulary that presents difficulties. It is not perfect; but it is practical.

I worked in seven locations in these two countries, as shown in Table 14.1.

Table 14.1 Locations of Focus Groups in Bulgaria and Romania Bulgaria

\begin{tabular}{|c|c|c|c|c|c|}
\hline Locations & Population & $\begin{array}{c}\text { Number } \\
\text { of }\end{array}$ & $\begin{array}{c}\text { Number } \\
\text { of }\end{array}$ & $\begin{array}{c}\text { Number } \\
\text { of }\end{array}$ & $\begin{array}{c}\text { Dates of } \\
\text { Interviews }\end{array}$ \\
\hline & & Schools & Groups & Students & \\
\hline
\end{tabular}

\footnotetext{
${ }^{1}$ I am particularly grateful to (Bulgaria): Katia Christova, Evelina Kelbetcheva, Katya Simeonova, Galia Slavcheva and Mirela Vasilva, and (Romania) Ciprian Ceobanu, Carmen Ceobanu, Magda Ciubancan, Magda Danicu, Carmen Dutu, Alin Gavreliuc, Aurora Goia, Tudor Iordachescu, Simona Laurian, Elena Mazareanu, Eleana Mitu, Monica Oprescu and Monica Secui; also the heads/principals of the schools and the students, and at London Metropolitan University, colleagues in IPSE, particularly Angela Kamara.
} 


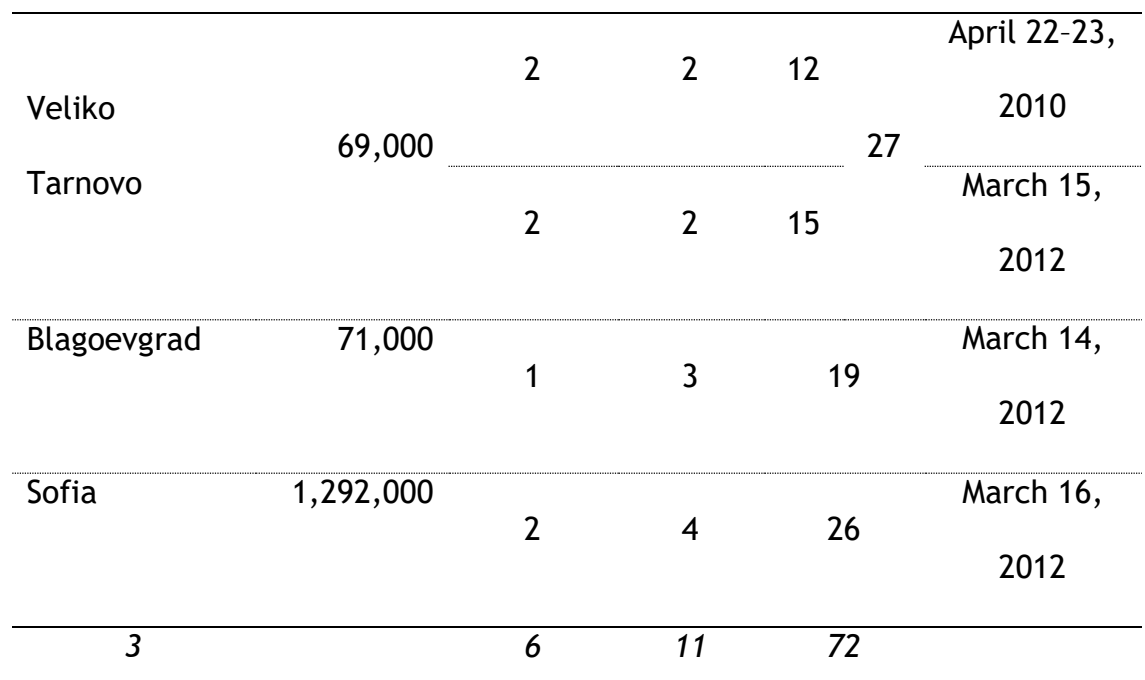

Romania

\begin{tabular}{ccccc}
\hline Locations Population & $\begin{array}{c}\text { Number } \\
\text { of }\end{array}$ & Number & Number & Dates of \\
& Schools & Classes & of & Interviews
\end{tabular}

\begin{tabular}{lccccc}
\hline Timișoara & 307,000 & 2 & 4 & 26 & October 11- \\
& & & & & 12,2011 \\
Oradea & 206,000 & 2 & 4 & 25 & October 13-14 \\
\hline lași & 317,000 & 2 & 4 & 30 & October 17-18 \\
\hline București & $1,930,000$ & 4 & 4 & 24 & October 19-20 \\
\hline 4 & & & & & \\
\hline 4
\end{tabular}




\section{$<$ A $>$ IDENTITIES IN CONTEXT}

I have used two particular frameworks in my analysis of the construction of identities in this analysis of these two countries. Michael Bruter (2005), analysing the emergence of mass European identity, describes territorial identities as having two component elements, the 'civic'-identification with 'the set of institutions, rights and rules that preside over the political life of the community' (12) — and the 'cultural'identification with 'a certain culture, social similarities, values' (12). This potential dichotomy between civic and cultural Lynn Jamieson and Sue Grundy (2007) describe how some young people 'come to present themselves as passionate utopian Europeans, while for many being European remains emotionally insignificant and devoid of imagined community or steps towards global citizenship' (663).

In addition to these frameworks, I will also raise a couple of specific themes that arose in Bulgaria and Romania that pervaded much of their talk: firstly, a tension between a sense of powerlessness and an assertion of agency in terms of their ability to participate effectively in Romanian society; and, secondly, a profound ambivalence about Romania's location within Europe. Liminality emerges as a defining theme. Many young people in both countries professed elements or quality of ambiguity or disorientation (Turner 1967): they appear conscious of 'standing at the threshold' between their own nationality and Europe, and in some ways to be oppressed, or at least isolated by each of these. The intersection of national identity and European identity created tensions and alienation. 


\section{<A>BULGARIA AND ROMANIA: A BRIEF BACKGROUND}

It might for some readers be useful at this point to provide a very brief outline of the development of these two states - much of this informs contemporary constructions of identities. The two countries, although neighbours with broadly similar economies, have had very different histories.

Bulgaria has a population of about 7.5 million people and, with a per capita GDP of about $€ 11,200$ a year, is the poorest country in the Union - the purchasing power per capita is about 45 per cent of the EU average. Romania has, in European Union terms, a large population of 21.4 million, and with a per capita GDP of about $€ 11,700$, it is the second poorest EU country: but it has a large territory (ninth in size in the EU). Both joined the EU in 2007, but neither is a member of the Schengen area or in the Eurozone. Both largely agricultural countries with a predominantly rural population in the late 1940s, by the 1980s had become industrial economies. Following the end of the Communist period (1989-1990) the shock of entering a market economy caused a sharp drop in industrial and agricultural production and economic collapse in the late 1990s. Growth in both countries was strong in the early 2000s, but contracted in 2009; since when growth has been positive, but low. Unemployment is at 7 per cent in Romania and 12 per cent in Bulgaria.

In the tenth century Greater Bulgaria was a large and substantial Balkan power, but then became provinces of the Byzantium Empire. The restored second Bulgarian Empire fell to the Ottomans at the end of the fourteenth century, and it remained part of that empire till 1876, when a poorly organised revolt was easily crushed by 
Ottoman troops: tens of thousands were massacred. The Russians, considering themselves champions of the Slavs and seeking to expand their hegemony toward the Mediterranean coast, declared war on the Ottomans, liberating most of Bulgaria by early 1878 . The consequent Treaty of San Stefano established a large autonomous Bulgarian principality, but the other Great Powers resisted the creation of a Russian client state of this size. The Treaty of Berlin, later in 1878, scaled back the Bulgarian frontier, and carved part of Bulgaria proper into a principality of Rumelia, leaving many ethnic Bulgarians outside the new country and setting Bulgaria on a militaristic approach to foreign affairs.

In 1885 they absorbed Rumelia, and in 1911 they allied with Greece and Serbia to jointly attack the Ottomans and partition Macedonia and Thrace between them. In the First Balkan War of October 1912 these allies took most of Turkey's European territory. Bulgaria tried to seize the largest share, but the Serbs refused to vacate Macedonia: Serbia and Greece formed a new alliance against Bulgaria, who lost the Second Balkan War of 1913 and had to relinquish most of Macedonia to Serbia and Greece. Maps of the boundaries before and after these wars are still on classroom walls in many schools in the Balkan states. In World War I the Bulgarians aligned themselves with Germany and Austria-Hungary (in return for a promise of acquiring Macedonia): they won military victories against Serbia and Romania, and in 1917 defeated Britain, France, Russia and Romania. But anti-war and anti-monarchist sentiment led to the proclamation of a republic in 1918. In the post-World War I settlements, Bulgaria ceded its Aegean coastline to Greece, recognised Yugoslavia (nearly all of Macedonia went to the new state), reduced its army to 1.5 per cent of its previous size and had to pay reparations exceeding $\$ 400$ million. Bulgarians generally 
refer to the results of the treaty as the 'Second National Catastrophe'. In the Second World War initial hopes of remaining neutral ended when the German forces demanded passage through Bulgaria in their attack on Greece in 1941. The Bulgarians formally joined the fascist bloc until August 1944, when the Romanians left the Axis Powers and declared war on Germany and allowed Soviet forces to cross its territory to reach Bulgaria.

The Soviet Union occupied the country, which became the People's Republic of Bulgaria, ruled by the Bulgarian Communist Party. After an oppressive Stalinist phase there was from the early 1950s a degree of liberalisation and economic development. Standards of living began to rise, but there was also an assimilation campaign directed against ethnic Turks in the 1980s: some three hundred thousand Bulgarian Turks left for Turkey, and agricultural production slumped. The collapse of Communist regimes in Eastern Europe after the summer of 1989 led to demonstrations in Sofia that became a campaign for political reform. Free elections held in the summer of 1990 were won by the Communist Party, ridden of its hardliner wing and renamed the Bulgarian Socialist Party. In 1991 a new constitution created a parliamentary republic with a directly elected president and a prime minister accountable to the legislature. The 1990s saw several changes of government and massive unemployment as uncompetitive industries failed and the backward state of Bulgaria's industry and infrastructure were revealed (Spirova 2010).

Romania, although like Bulgaria largely Orthodox Christian, has a Romance language that marks the inheritance of the Roman Empire in the second and third centuries. 
Three principalities of Wallachia, Moldova and Transylvania emerged in the middle ages. Transylvania became an autonomous part of the Hungarian kingdom — there is a substantial Hungarian population still there - whereas Wallachia and Moldavia had a greater degree of independence. By the mid-sixteenth century, all three, and most of Hungary, became Ottoman provinces. But the provinces maintained a large degree of internal autonomy. Transylvania was absorbed by the Hungarians in 1700, and the Russians annexed eastern Moldavia in 1812. Nationalist uprisings in the first half of the nineteenth century against the Ottomans led to the new United Provinces of Wallachia and Moldova in 1859: Transylvania remained with the Austro-Hungarians, who were seen by the Great Powers as a more powerful bulwark against Russian expansion. Romania sided with the Russians in the Russo-Turkish War in 1878 that liberated Bulgaria, gaining some territory as a consequence. Romania joined the Allied forces in 1916 in return for a promise that it would be given Transylvania, which was subsequently agreed at the Treaty of Trianon in 1920, creating România Mare: 'Greater Romania'. In the Second World War Romania also initially attempted neutrality, but first Soviet and then Nazi pressures led to Romania joining the Axis powers (loosing Transylvania to the Hungarians and southern Dobruja to the Bulgarians). Romania was a major source of oil for the Axis powers, but the Soviet army moved into Romania in August 1944, and a coup led to Romania changing sides.

The Soviet occupation led to the establishment of a Communist government, and Romania was under direct military occupation and economic control till the late 1950s. The Romanian government used the Securitate to eliminate state enemies. Nicolae Ceauşescu came to power in 1965 and pursued policies more independent of 
the USSR — condemning the invasion of Czechoslovakia in 1968, for example. This led to substantial Western investment, but pressure from the World Bank and International Monetary Fund then led to Ceauşescu reimbursing all foreign debt through policies that impoverished the Romanian people — and reinforced the powers of the police state and his own personality cult. Stan (2010) observed 'of all communist Central and Eastern European countries, Romania remained the least reformed, the most likely to deny basic human rights, and the only one with a sultanist-cum-totalitarian regime right up (to the moment when communism collapsed)' (380).

In December 1989 the Romanian Revolution became the most violent and forceful overthrow of a Communist regime. There were over eleven hundred deaths, including the execution of Ceauşescu and his wife on Christmas day. However, the leaders of the revolution were essentially Communist leaders who were disaffected with Ceauşescu's personality cult. The National Salvation Front took some partial 'original democracy' and liberal marketisation measures, but did not renounce Communism. Romania developed closer ties with Western Europe, joining NATO in 2004, and the European Union in January 2007. Romania has a growing diaspora of about two million people (in Spain, Italy, Germany, Austria, the United Kingdom, Canada and the US) (Stan 2010).

\section{$<$ A > HOW DO YOUNG PEOPLE CONSTRUCT THEIR IDENTITIES?}

These histories have a continuing effect on the narratives recounted in school curricula. For the purposes of this study, these events have meant that these young 
people have had radically different experiences to those of their grandparents and parents. Do young people identify with the cultural and civic aspects of Europe? Do they use the same components in their identification with their country? Are they passionate or indifferent about each? Do they acknowledge a multiplicity of identities, or is their identity singular and essentialist? Does their sense of identity require the construction of 'the Other', an alien identity held in juxtaposition to their own identity? This question is of particular significance to the subjects of this study: As the borders of the European Union continue to demonstrate their flexibility, are there (in the minds of these young people) limits to Europe? Where does the frontier lie?

Focus groups offer a powerful way to address these questions. My opening question challenged them to describe themselves and their identity. What did it mean to them to be Bulgarian or Romanian? How else might they describe themselves, and did they think their parents and grandparents feel this in the same way as them? Did everyone in the country feel the same? I then asked if they sometimes felt European, and how they might describe the characteristics of a 'European'. Finally, I asked them to consider the possible advantages and disadvantages of particular other countries joining the European Union. Could, for example, Russia or Turkey or Serbia become a member of the same club? These countries, as will have become clear, had various historical relationships with each of these two countries.

Analysis of the discussions showed a wide variety of responses, but there were some particularly interesting trends evident. The ways in which they expressed their identification with their own country were often qualified: There were reservations 
about what were sometimes seen as shortcomings in their compatriots. These in turn made them uncertain about having a sense of European identity: Europeans were thought to have behavioural characteristics that were not (or could not) be matched by Bulgarians or Romanians. They might be members of the European Union, but nevertheless felt that they were accepted on sufferance, and that they were not really European —or, at least, not European yet. Neither nationals nor Europeans, they were in a liminal borderland situation, neither one thing nor the other. Asking if Russia or Turkey might be thought of as European produced further confusion and possible marginalisation. The intersections of national identity and European identity produced uncertainty.

\section{$<\mathrm{B}>$ National Identities}

In both countries there was certainly evidence of pride in the country by many young people. This was sometimes simply seen as a natural response to having been born and brought up in the country. For example, Basia K (BG 9 173/4) described Bulgaria as 'my native country, it's my home. I feel like I'm in the right place. I want to be here' (her father was a construction worker and her mother unemployed). In Romania, Oana N ( $913^{1 / 2}$ ) said, 'I have been in many countries, and here I feel like home. There, when I am on the street, I feel very strange'. But Erika I $\left(\rho_{+} 16^{3 / 4}\right)$, in Timisoara, was not unusual when she said, 'Being Romanian doesn't mean that much to me. I mean this is the country where I was born—but I don't feel related to it. This is my house, but not my home'. Nationality was simply an ascribed characteristicand not the most important one. Two Bulgarians put this succinctly: 'I think it doesn't matter if we are Bulgarian, or if someone is Turkish ... the nation doesn't matter, we are all human, and we have to be open to other countries, other nations' (Pavlina $\mathrm{P}, q$ 
$15 \frac{3}{4}$ ); 'I am proud of being Bulgarian, too, but in these days the nation is just a formality. It doesn't matter where you are born, or where you come from' (Gavril D, Oे $\left.15^{1 / 2}\right)$

These feelings of pride in one's country were related to both history and culture, rather than political institutions and the structures of the state. Particularly in Bulgaria there were references to pride at having survived the 'five centuries' 'under the Turkish yoke'. Borislav T ( $\left.\delta^{\lambda} 16^{3} / 4\right)$ said, 'We have been five hundred years under Turkey, but we had the power to rise and take our country again, after five hundred years, which I think is pretty good thing to do-because five hundred years, for you to keep your nationality alive - this is something big'. But the references to Bulgarian culture sometimes included implicit or explicit recognition of the Ottoman elements within this, as when Vladislav $\mathrm{P}\left(\hat{\sigma} 12^{1 / 2}\right)$ talked of 'Bulgarian traditions are some of the most colourful — their songs and their food — and ayran is very good' ${ }^{2}$ or when Valentin P ( $\overbrace{}^{1} 16^{1 / 2})$ referred to the culture as 'really interesting, because we're right on the border of Europe and Asia, and we have something from both cultures'. There were as many references to historical pride in Romania, such as Daniela D ( 9 171/2): 'Being Romanian means having a certain respect for the historical people, and I'm very proud that, after several wars and fights with other powers, we managed to be all right in the end, even if we are not as good as the other countries'.

\footnotetext{
${ }^{2}$ Ayran: a cold beverage of yogurt mixed with cold water and sometimes salt; it is popular in many Central Asian, Middle Eastern and south-eastern European countries.
} 
The second major area of national pride in both countries was in the natural landscape and the flora and fauna. But this was frequently qualified with references to how some of their compatriots' disregard the environment, and pollution and littering were often mentioned. In Bulgaria, Arnost M ( $\delta_{123 / 4)}$ said, 'Pollution is everywhere—all the people throw their waste on the roads. In the forests they cut down trees, and they just destroy the nature in Bulgaria'. And in Romania Silvia P (q 16) said, 'We do not know how to appreciate [the country] - to preserve this, not to throw garbage on the streets'.

In parallel to expressions of positive feelings for the country were widespread criticisms of the way in which Bulgarians and Romanians behaved. In both countries there were many ad hominem comments that 'people' (a term that apparently did not include the young people in the discussion groups) had ways of thinking (often 'a mentality') that was selfish, anti-social or simply old-fashioned. Thus Mircea D (우 $16 \frac{1}{4}$ ), a worker's daughter in western Romania, said, 'Sometimes you are ashamed of being Romanian, because other people do all kinds of unpleasant things'. Fellow citizens often behaved badly, especially those working abroad, and the Roma minority were particularly criticised in Romania (less so in Bulgaria). In both countries, politicians were criticised as self-serving and often corrupt. These factors, they said, led to their countries being perceived badly by members of other European states. The following paragraphs examine each of these assertions in turn.

In both countries there were complaints that people were inclined to talk about problems, rather than actively seek solutions. In Bulgaria, Branimir B $\left(\delta^{\Uparrow} 16^{3} / 4\right)$ said he 
was 'not proud that Bulgarians talk, but they don't take action when they ... don't like something'. People were selfish, and there were popular expressions about this: in Romania, Ionut M ( $\left.{ }^{\Uparrow} 14 \frac{1}{4}\right)$ said, 'They care only if my dog dies, the neighbour's dog should die, too', whereas in Bulgaria, Borislav T $\left(0^{1} 16^{3} / 4\right)$ said that 'we look at the other [person]'s plate. If I have a problem, I want my neighbour to [have one], too. ... There is a pot in hell full of Bulgarians-nobody can get out of it, because each person pulls down the others'.

There was, they claimed, a common disregard for civil rights: Nikolai C (BG $\overbrace{}^{\Uparrow} 15^{1 / 2})$ said, 'We don't search for our rights — in other countries, you see something that you don't like, you ... tell the police and they take the case- - problem solved. But in Bulgaria you just close your eyes to it, and don't pay any attention to what happened'. Izabela $\mathrm{U}(\mathrm{RO} \circ \mathrm{16})$ said (in a rare reference to gender equality) that 'in Romania that the men are seen as more important than the women - the man defines the place'.

Several Romanians said that their compatriots were feckless. Ionut M ( $\widehat{0} 141 / 4)$ : 'my country ... has people who are like sheep. They follow each other, they do as their neighbours'. Gabi B (ð 11/1/2) said, 'People in Romania ... want to finish work too soon, to work less'. Bulgarians were said to have antiquated patterns of thinking: When Daniel B ( $\left.\delta 16 \frac{1}{2}\right)$ said, 'I think our thinking is old. We are not open-minded

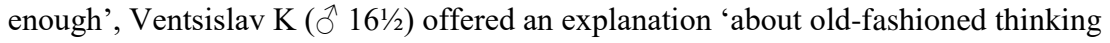
... this is because we have been slaves for about five hundred years - this is why we are not so modern and open-minded'. 
In Romania, the Roma minority in particular were criticised, and there was some indignation that this community had appropriated the term 'Roma': Several said that the Roma were not Romanian. Lucian S $\left({ }^{\lambda} 12^{3} / 4\right)$ asserted that 'the Gypsies are harsh and they mug you and try to do a lot of bad things'. Nina A ( 9 143/4) said that they 'were not Romanian, they are different from the Romanian people- they are their own nationality. Europeans make this confusion, that Romanians and Gypsies are the same'. 'Our reputation is very low because the Gypsies who are born in Romania have Romanian passports - they are not really Romanians', Dumitru D (ठึ 141/4) explained. Even expressions of sympathy were constructed through terms of 'othering' and blame: Jean R ( $\left.\sigma_{171 / 2}\right)$ 'the Gypsies ... don't realise that they are the ones who trigger that attitude from us, because they are the ones who have misconduct'. In Bulgaria, attitudes appeared rather different: speaking of minorities within the country, Nikola A (ð 16) said, 'Some ethnic groups which are isolated from the social life of Bulgarian ... society—-they won't feel as patriotic as the notisolated Bulgarians-Gypsies, Turkish, [those] kind of people'. Anti-Roma feeling was associated with older generations: Aleksandar C ( ${ }^{\wedge} 13 \frac{3}{4}$ ) said his 'grandfather thinks that all the problems in Bulgaria come from the Gypsies and marginal groups', to which Teodor T ( $\left.\delta^{1} 13^{1 / 2}\right)$ added, 'the Roma are not bad people-I [think] ... that it's people from all groups who make problems - the problem isn't just in this group'.

In both countries, politicians were criticised as self-serving and often corrupt. In Bulgaria, Toma S ( $\overbrace{12}^{1} \frac{1}{2})$ said, 'Politicians are liars .... most Bulgarians don't like Bulgaria because of the government'. Anton L ( $\left.\sigma^{\Uparrow} 17 \% / 4\right)$ said, 'they stole assets', and Bogdan $\mathrm{G}(\lesssim 13)$ that 'the president or the prime minister ... say they will do something about the problems, but do nothing, just get votes and take the money'. In 
Romania, Cosmin L ( $\left.{ }^{\Uparrow} 13^{3} / 4\right)$ claimed, 'The government simply destroys everything. The people ... hate the government, but they keep voting for the same rubbish leaders, again and again'. Corruption was mentioned frequently: Marian T ( $\left.ぇ 15^{3 / 4}\right)$ was 'very concerned about corruption - in Romania there is a lot ... especially at a high level'. And Ana P (q 13ํํㄹ) said, 'President Băsescu has I don't know how many houses! All our money is in their pockets, and nobody does anything about it'. In Bulgaria, Sergei $\mathrm{S}(ð 16)$ complained, 'What pisses me off is that we see corruption at the lower levels - there is a corruption everywhere, but in other countries its at the higher levels and people don't see it'.

These behavioural characteristics were all seen as contributing to the poor perception of their countries by members of other European states. This was sometimes based on personal experiences, or those of family members: Abela $F\left(\hat{\jmath} 14 \frac{3}{4}\right)$, from Romania, said she 'went to France for a summer vacation-I spoke with my parents in Romanian, and everyone was looking at us in the metro like this [arms crossed across front to guard wallet, bags, etc] — with their bag and that—being Romanian these days isn't very nice, because we are seen as thieves, Gypsies and so on'. Milenka P (BG $ᄋ$ $13^{3} / 4$ ) described how her brother 'has been living in Germany for about seven years, and he says that when he says he's a Bulgarian he's treated not as a person'. Some were aware of negative media attention: In Bulgaria there were references to a recent right-wing Netherlands political party's website that had been making derogatory comments about Bulgarians: Toma $\mathrm{S}\left(\widehat{\delta} 12 \frac{1}{2}\right)$ said that as a consequence, people in the Netherlands "when they hear Bulgarian they think "Oh, this is rubbish", because our reputation in Europe is very, very bad'. 
These comments were frequently tinged with expressions of a sense of powerlessness, that they lacked the agency to affect society and politics. In Romania, Olga M ( +16$)$ said, 'We don't have the power to change ... we've tried to change the president and to encourage our parents to vote for someone else — but it's still the same-men want power, and when they have it, they make use of it'. And Amelia S (q 16.0) felt, 'We cannot make any changes because of the bad things, and the bad systems have very deep roots'. There were also assertions that they could make an impact: Amelia S also said, 'We are responsible, being Romanian. We have our rights and responsibilities, and we have to improve the situation — not only ours, but the others around us', and Basia K (q 173/4) said, 'The future of Bulgaria is in our hands, our generation's' - to which Ivana P ( $\$$ 173/4) retorted, 'Yes—but if you go abroad, you will not change anything'. This issue, of young people wanting to migrate from Bulgaria or Romania, was divisive. Borislav T (BG $\left.\delta^{\lambda} 16^{3} / 4\right)$ explained that 'there are two types of people of our age now-people who want to leave, who don't want to live here and think that if they go abroad they will have a better life — and people who are proud of being Bulgarian, who love the country and want to stay. I think the first kind is bigger-a lot of people want to leave'. This group was exemplified by the comments of Fidanka M (q 16) - 'I don’t think that Bulgaria will provide me with a good job, because the payment is very low ... I have ambitions to work in Europe. Or in America', and of Anelie V ( 9 163/4) — 'maybe in the future I won’t live here—I don’t like the country'.

These young peoples' identification with Bulgaria and Romania respectively appears to be strong on the cultural side: There were many expressions of affection for the country. But this was a feeling of warmth, rather than of chauvinism. There were very few remarks that could be construed as nationalistic, and a number that were 
explicitly non-nationalistic or showing sympathy for a more global identification. But there was also a pervasive critical element about aspects of Bulgarian and Romanian behaviour, and references to outdated 'ways of thinking' and to conduct that they thought inappropriate. Generally there were few references to the institutions of either state, apart from historical references to independence.

\section{$<$ B $>$ European Identities}

This sense of uncertainty and diffidence about their construction of a national identity was paralleled in the European sphere. A European identity was acknowledged by some, but a sense of distance, of hesitancy, about 'being part of Europe' was more commonly articulated. Most saw European identity as distinctly subordinated or secondary to their sense of being Romanian or Bulgarian. Thus Mihail B (RO $\left.\sigma^{\pi} 15^{3 / 4}\right)$ said he felt 'more Romanian than European - I don't really have the thought of being European that often'. Others said that they were European simply in the geographical sense: Nikola A (BG $\widehat{O} 16)$ said that 'every country that is in the territory of Europe, every nationality, should feel European ... it doesn't matter if it's in the European Union or not—we're all European, even though some countries aren't as advanced as Germany, Italy, those kind of countries'. Vladimär M (BG $\left.\sigma^{\Uparrow} 13^{1} \frac{1}{2}\right)$ said, 'I don’t think we should feel European - we are in Europe, on the continent'. For others, it was simply a consequence of European Union membership that made them European: so Todor R (BG $\lesssim 14)$ asserted, 'We are surrounded by Europe. We are part of the European Union, and we became [a member] in 2008'.

But many of these and similar expressions concerned Bulgaria or Romania as a country being European, rather than being individual feeling of a European identity. 
Many suggested that they might, as Romanians or Bulgarians, be European in a titular sense, but that in reality this was not accepted by 'the Europeans' themselves. Others said that they did include a European dimension in their identity, but they were also aware of being rebuffed in this. 'They' were constructed as something different from 'us' and Europeanism was to be defined on 'their' terms. Consequently, some of these young people felt that Europe had rejected them — or at least, had not accepted them (as in the example of the Netherlands in the preceding). So Abela F ( $\mathrm{RO} \curvearrowright 14 \%$ ) said, 'In the registers, they say we are, we are Europeans—-but I don't feel like it', and Loredana Z ( $\left(13^{1} \frac{1}{4}\right)$ said, 'I feel European, but the other people in Europe discourage

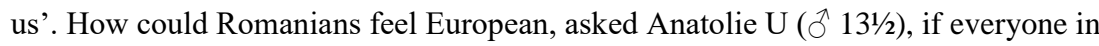
the other European countries 'says that we shouldn't be in the European Union, and that we don't deserve to be?'

There was a sense that 'being European' meant either belonging to a more developed economy or to having a different culture and mentality. In Bulgaria, Rada V ( $q$ 151/2) simply said that 'the other countries in Europe are much more advanced than us', and Fidanka M ( 9 16) said she found it 'a little hard to feel like Europeans, because there are some big differences between the Bulgarians and some European countries'. In Romania, Mirela B (q 16\%3) claimed that to be European 'means being part of a developed country, being respected'. Being a European meant behaving in a particular (and non-Bulgarian) way for Teodor T ( $\left.{ }^{\Uparrow} 13 \frac{1}{2}\right)$ : 'I feel Bulgarian when I see someone throwing trash in the streets; I feel European when I make him pick it up and put it in the bin'. Europeans were in some way better able, or more likely, to follow social rules. Although the examples often given were of throwing litter on the street, there was a sort of bystander response (Darley and Latané 1968): Bulgarians and 
Romanians would not follow rules (the young people said) unless everybody else followed them. Vladimär M (BG $\left.\widehat{\delta} 13^{1} \frac{1}{2}\right)$ suggested that 'maybe their [i.e.

European's] rules make them different from other people ... they are actually trying to do something', and Elisaveta M (q 161/2) said, 'It's a question of our thinking ... maybe they [Europeans] keep with the rules, because here in Bulgaria we are always saying, "why should I do it, because the person next to me isn't doing it?"”

In particular, 'Europeans' were held to have a different mind-set, a different 'mentality' to the Bulgarians and Romanians. Anelie V (BG $\odot$ 16³/4) said, 'I don’t feel like a European person ... everyone thinks only for themselves, out of self-interest'. For Elisaveta M (BG + 161/2), 'it's not about how we feel; it's about our thinking'; Borislav T $\left({ }^{\lambda} 16^{3 / 4}\right)$ echoed this_-'our thinking is not like theirs .... people from Europe [are] better in the things [they] do ... much better mannered ... bettereducated people’. Olga M ( $(+12)$ talked at length about striving to be European and to be different: 'Bulgaria in some ways doesn't let me be a European, because I don't always think before I act ... that's why I want to be a European someday. ... Europe is different because of its culture and its heritage — people in Europe are more selfaware'.

Europe was 'over there' in the West, a different place where they behaved differently and in what was seen as a more 'civilised' way. Vladislav P (BG $\sigma^{1} 12 \frac{1}{2}$ ) explained that 'to be European ... you must behave like a European, and Bulgarians don't behave like this ... Europeans behave very well, they are polite to shop assistantssome Bulgarians are rude to them; and in European countries everyone has manners'. 
Dumitru D (RO $\lesssim 14 \frac{1}{4}$ ) also felt that 'they [Europeans] are not too different from us, but they have a higher intelligence level than we have - and they are more civilised' It seems that what ran through many of these comments was a sense of not feeling fully European, or fully European yet. For some, this was simply a matter of material progress: Borislaw A (BG ${ }_{0} 12 \frac{1}{2}$ ) said that in Greece he had seen little pollution and well-made streets - 'it makes people have a European sense. In Bulgaria we have the opposite — so we are not Europeans’. Gala I (q 13\%3/4) said she ‘would feel European if we could end the problems that are affecting our parents; the lack of work'. Europe was thus, in a sense, elsewhere, not to be found in this part of the world. Vlad P ( 171/4) spoke of Romanian culture as Eastern European: 'in the Balkan regions there are very powerful Slavic influences'; for him, the heart of Europe was in Western Europe- 'the bedrock of Europe, so to speak-it has achieved some degree of cultural dominance'. Madalina $\mathrm{B}(\mathrm{RO}+16 \%$ ) referred to Europe as 'in Finland and those countries, they are more civilised and organised'.

There was a sense of liminality, of being on the border of being European and perhaps of anticipation of the potential to cross that frontier. Toma $S\left(\widehat{\jmath} 12 \frac{1}{2}\right)$ said, 'I don't think we are Europeans yet .... The country is not really European, because it's not improved to a European level, so it's not European yet'. Nikolai C ( $\left.\delta^{\lambda} 15^{1 / 2}\right)$ put it this way: 'We've been through bad times ... that's why it's a bit harder for us to accept ourselves as part of Europe'. Valentin P (BG $\delta^{1} 16^{1 / 2}$ ) said, 'I think that in five, ten years' time we will say that we are European'. Both Romanian and Bulgarian young people had a view that their countries were marginal to Europe and marginalised by Europe. They seem aware that they may be on the threshold of some new, European way of political and cultural expression (Thomassen 2009). In a period of liminality 
social hierarchies are in flux, traditions may become indeterminate and the future of these young people see for themselves is fluid and uncertain (see Horvath, Thomassen and Wydra 2009).

A few instead—or as well—asserted an alternative Balkan identity: Sergei S (ð 16) is typical of these: 'I mostly feel like a man from the Balkans, not so much a European because we have a different structure here, in our thinking. I don't feel like a person of my age from England or France, for example—we have a lot of differences—but a guy from Serbia or Montenegro, I think I'd be similar to him'. Europe was somewhere else, said Gogu G (RO $\curvearrowright 141 / 4$ ) —it was 'Germany, France, Italy, Spaina lot of countries. I guess it's about us, and maybe the Bulgarians - we didn't take advantage of being in the European Union until now. ... They have another way of thinking - they think differently to us'.

Europe was thus for some of these young people a problematic construct. It was in some senses a desirable attainment, but as yet not achieved, and at the same time had an exclusiveness that meant that they felt rejected. Europe was thus seen partly as cultural—something that Bulgarians and Romanians 'ought' to share, but of which there was some uncertainty, and also to do with something described as 'behaviour', which seemed to encompass activities from financial probity to being conscious not to litter the streets, where it was felt that they fell short. But Europe was seen also as institutional, and here there was a greater sense of focus and of anticipation. Yet Europe, in an emotional sense, remained distant, cut off partly by the attitude of 'other' Europeans to them, partly by their own distrust of their 'mentality'. 


\section{$<$ B $>$ Constructions of European Identities and of the Boundaries of Europe}

These constructions were given a different twist when groups were asked to consider the possibility of particular other potential partners in the European Union. I asked them first to consider the possibility of Russian membership and then Turkey: Both countries have played significant roles in their countries' histories. Instead of presenting short quotations from different groups, I now present some longer extracts from a single group in Iaşi, Romania.

Asked if they felt that they might consider themselves as European, Cristian T ( $\partial^{\star}$ $16^{1 / 2}$ ), son of a builder and a postal delivery worker, said:

No, I don't think so. Because we can't compare ourselves to European countries like Germany, England, France, Spain, maybe - we aren't in the same bracket.

I asked if Romania was part of the European Union:

Cristian T: Technically. On paper.

Beryx D (ô 16, parents booksellers): Up till now, I've never felt that I'm European ... and if I felt it, I never got help from anybody—nothing changed. 
Several minutes later, I asked how Europeans were different from other people:

Cristian T: A sort of breed of efficient people — and wealthy countries — that's about it. Yes, you must have something in common to create a union. You don't have a culture in common, so what remains in the industry? The economy.

Beryx D: In Europe, most countries are at the same level-for example, in Germany, if someone has a problem—-let's say an incurable diseasethe state helps him—gives him money, gives him a place to stay ... In Romania, no one helps you, you remain on the streets. It's not the same, even if we are in Europe. No one helps us.

And then, further into the discussion, I introduced the idea of Russian membership of the European Union.

Cristian T: I think they can't [join] because if we look at the history, they always did different. While we have economic downturns, they register 400 per cent increases, and being such a big country—sort of hungry for more land, for more power - they wouldn't cooperate well with the European Union. They ... I don't see them as people who can obey rules very easily, and have common sense. 
Andrei M ( $\overbrace{}^{\lambda} 15^{3 / 4}$, father an engineer): I also think that it's not possible ... countries that [become] a member of the European Union should be those on the European continent.

AR: $\quad$ I'm interested in what you said about Russia being different from ..... from whom? From Europe, or from Romania?

Cristian T: I think from Europe because we try to be sort of politically correct here, and they don't really — they have a sort of — We, we Europeans as well—especially you British people—have a history, a habit, of exploiting underdeveloped countries, colonies and so on. But they have a bigger habit of doing this, and a more recent habit of doing it.

AR: $\quad$ Do you agree with what Cristian T says?

Several: $\quad$ Yes, yes.

AR: I'm going to press you on this-because you're now talking about 'we Europeans'-

Cristian T: Aghr! [exasperation at being caught out, and recognition of what he's said]

AR: $\quad$ But before you said that you didn’t feel European. Can you explain this sort of thinking?

Cristian T: Yes, yes, I know ... as a mentality, as a country, I think of us being exactly in the middle- I think we incline to be more European-ish than Russian. We, we evolved towards the European, I think. 
When the possibility of Turkish membership was introduced, Andreai M was in favour, despite it being located on two continents, but now Cristian T argued that 'Russia is much more European' [geographically]. Andreai T agreed: 'Well, yes, Russia is much more European because their people are more like us, they even look more like us-Turkish people, they have a different colour of their skin'; to which Emil V (o 141/2) retorted, 'The culture isn't that different'.

Identities at this point become contingent and multiple. Compared with the European Union states, Romania (and, to a lesser extent, Bulgaria) are seen as outside the group. Compared with Russia, both countries moved across the border and became

European.

Many in Bulgaria were less opposed to potential Russian membership: Some felt that all countries that were in Europe, or even partly in Europe, should become members, whereas others perceived Russia as a rich and powerful state that would help the Bulgarian economy. But there were also references of cultural and historical affinities and divergences: Violeta $\mathrm{G}\left({ }_{+}\right.$121/4) said, 'We have almost a common language’, whereas Olga ( $(12)$ thought, 'Russians and Europeans are different, maybe that difference would make them feel uncomfortable. ... Not only the culture, but the way the people think, the way the people act'.

For some of the Bulgarians, Turkey was a particular issue: Ventsislav K $\left({ }^{\lambda} 16^{1 / 2}\right)$ argued, 'I don't think I would like it if Turkey joined-I don't really like them that much, because we've been their slaves for five hundred years' - to which Vladimära G (q $\left.16^{3} / 4\right)$ replied, 'It's a different generation, and we are not slaves any more, and it 
doesn't matter that we have been under them for five hundred years'. Similarly, Petar

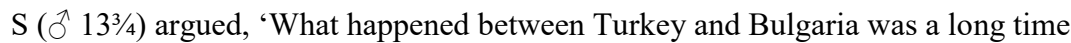
ago - in the same way it happened in World War II with Germany and the whole world — nowadays Germany and the other countries are friendly with each other, and so, I think Turkey and Bulgaria should be the same'. Several Bulgarians argued that Turkey was too different culturally, and in doing so (as with Cristian $\mathrm{T}$ in Romania) re-orientated their own sense of being European. Thus Valentin P $\left(\delta_{16}^{1 / 2}\right.$, parents own a small company) initially said that when he went to other European countries, 'I feel a bit different from them, and not like [a] typical European', but later he said, 'When I went to Turkey, I felt European; when I saw their culture and how they live - the culture is different than ours, and I felt European there, because it was different ... For Turkey to become a member of the Union - their culture is very different, and I don't know how they will reconcile their culture and religion ... I don't think they will feel European'. There appeared that, particularly in comparison to Turkey, that there was a European culture and one that Bulgarians might possibly share. A European culture was initially questioned, and sometimes denied, but sometimes followed by a recognition that — when Turkey could be 'othered'- there was a common culture with other Europeans.

\section{$<$ A $>$ SOME TENTATIVE CONCLUSIONS}

Bulgaria and Romania present an interesting paradigm in studies of the new Europeans. These young people present not just multiple identities, but a confusion of multiple identities: proud of Bulgaria or Romania, but sometimes rejecting it - their country could be modern, prosperous and 'European', but also had a people whose 'ways of thinking' condemned the country to be marginalised, relatively impoverished 
and unchanging. Theirs was a country in which they could perhaps think that they might live and work in for the future, but also a country that they should leave, perhaps permanently; marginalised in Europe, but also integral to Europe and at one with it in terms of modernity and outlook; in close cultural harmony with their parents and grandparents, but also on the threshold of a new generational attitude. They were insiders and outsiders.

These constructions strain both Bruter's (2005) and Jamieson and Grundy's (2007) models of European identity. Were they attached to cultural or to institutional aspects of their country or of Europe? In some ways, they were detached from both. Neither Bulgarian nor Romanian institutions of government were a focus for identification: but there was also a sense of bipolarity about the culture of their country. Aspects like the natural beauty, the history and the past were strong themes around which rapport was established, but there was ambivalence about the cultural traits of the respective peoples, a sense of distancing themselves from the way that 'Bulgarians thought' or 'Romanian thinking'. Passionate enthusiasm or indifference? Both were evident, often expressed by the same individual. There were similar paradoxical relationships with Europe: Whereas the institutional structures were welcomed - the mobility, the prospects of study abroad, the financial support for the country and sometimes the emphasis on rights - the degree to which there was an identification with this is less clear. The same is true of the cultural and behavioural aspects of Europeans. In both cases these were admired, but not fully participated in: partly because of their compatriots own behaviour. Romania and Bulgaria became liminal, territories on the border of Europe. But when the lens was shifted to examine states beyond the 
European Union, then institutional and cultural affinities with Europe moved to the fore: Indifference became sometimes a more ardent attachment.

The implications of this for educational settings will become increasingly important for Western European countries, as these two countries join the Schengen area in 2014. From that year there will be free movement of labour from these countries, and there are anticipations that, as in the European expansion of 2004, there will be reasonably substantial numbers of workers and their families arriving in Britain, France and Germany in particular. Romania in particular has a relatively large population. Many schools will have pupils from these countries: Young people who will feel a strong sense of inferiority when they compare themselves with the 'real' Europeans who constitute their classmates. Unlike many previous children who have migrated from other European backgrounds, these young people will have no strong sense of national identity, other than an affection for the natural beauty of their countryside. This ambivalence may make itself apparent in various ways, but they are likely to be particularly vulnerable to criticisms or aspersions about their country of origin, being conscious of being stereotyped disadvantageously. At the same time, they will be disorientated by the diversity of the societies they now find themselves in: With a well-developed sense of social and national gradations and hierarchies, they may try to position themselves above some other migrant groups (and perhaps particularly to Roma or Traveller peers), using terms and attitudes that many teachers and other pupils will find difficult and problematic, even racist. It will require particular sensitivity to understand and react positively to their constructions of themselves as liminal beings, uncertain of how their mix of identities socially positions them in their new home. 


\section{REFERENCES}

Browne, Irene, and Joya Misra. 2003. 'The Intersection of Gender and Race in the Labor Market'. Annual Review of Sociology 29:487-513.

Bruter, Michael. 2005. Citizens of Europe? The Emergence of a Mass European Identity. London: Palgrave Macmillan..

Collins, Patricia. 2000. ‘Gender, Black Feminism, and Black Political Economy’. Annals of the American Academy of Political and Social Science 568:41-53.

Crenshaw, Kimberlé. 1991. 'Mapping the Margins: Intersectionality, Identity Politics, and Violence against Women of Color'. Stanford Law Review 43 (6): 12411299.

\section{Darley, John \& Latané, Bibb. 1968. 'Bystander intervention in emergencies:}

Diffusion of responsibility'. Journal of Personality and Social Psychology 8 : $\underline{377-383 .}$

Horvath, Agnes, Bjørn Thomassen and Harald Wydra. 2009. 'Introduction: Liminality and Cultures of Change'. International Political Anthropology 3:3-4.

Jamieson, Lynn, and Sue Grundy. 2007. 'European Identities: From Absent-Minded Citizens to Passionate Europeans'. Sociology 41 (4): 663-680.

Joppke, Christian. 2001. Citizenship and Immigration. Cambridge: Polity.

Licata, Laurent. 2000. 'National and European Identities: Complementary or Antagonistic?' Paper presented at the ID-NET conference, European University Institute, Florence, Italy, June 9-10.

Formatted: Font: $12 \mathrm{pt}$

Formatted: Font: $12 \mathrm{pt}$

Formatted: Font: $12 \mathrm{pt}$

Formatted: Font: $12 \mathrm{pt}$, Not Bold

Formatted: Font: $12 \mathrm{pt}$ 
Lutz, Wolfgang, Sylvia Kritzinger and Vegard Skirbekk. 2006. 'The Demography of Growing European Identity'. Science 314: 425.

Mackenzie, William. 1978. Political Identity. Harmondsworth: Penguin.

Marshall, Catherine, and Gretchen Rossman. 1999. Designing Qualitative Research. 3rd ed. London: Sage.

McCall, Leslie. 2005. 'The Complexity of Intersectionality'. Journal of Women in Culture and Society 30 (3): 1771-1800.

Ritzer, George. 2007. Contemporary Sociological Theory and Its Classical Roots: The Basics. Boston, MA: McGraw-Hill.

Siltanen, Janet, and Andrea Doucet. 2008. Gender Relations in Canada: Intersectionality and Beyond. Oxford: Oxford University Press.

Spirova, Maria. 2010. 'Bulgaria since 1989'. In Central and Southeast European

Deleted: 0 Politics since 1989, edited by Sabrina Ramet, 401-420. Cambridge: Cambridge University Press.

Stan, Lavinia. 2010. 'Romania in the Shadows'. In Central and Southeast European Deleted: 0 Politics since 1989, edited by Sabrina Ramet, 379-400. Cambridge: Cambridge University Press.

Thomassen, Bjørn. 2009. 'The Uses and Meanings of Liminality.' International Political Anthropology 3:51.

Turner, Victor. 1967. The Forest of Symbols. Ithaca, NY: Cornell University Press. 